\title{
CRITICS TO METAPHYSICS BY MODERN PHILOSOPHERS: A DISCOURSE ON HUMAN BEINGS IN REALITY
}

\author{
Frederikus Fios \\ Character Building Development Center (CBDC), Bina Nusantara University \\ Jln. Kemanggisan Ilir III No. 45, Kemanggisan - Palmerah, Jakarta 11480 \\ Fios2013@yahoo.co.id
}

\begin{abstract}
We have entered the 21st century that is popularly known as the era of the development of modern science and technology. Philosophy provides naming for contemporary era as postmodern era. But do we suddenly come to this day and age? No! Because humans are homo viator, persona that does pilgrimage in history, space and time. Philosophy has expanded periodically in the long course of history. Since the days of classical antiquity, philosophy comes with a patterned metaphysical paradigm. This paradigm survives very long in the stage history of philosophy as maintained by many philosophers who hold fast to the philosophicalepistemic claim that philosophy should be (das sollen) metaphysical. Classical Greek philosopher, Aristotle was a philosopher who claims metaphysics as the initial philosophy. Then, Immanuel Kant, Hegel, Heidegger, Marx even Habermas offer appropriate shades of metaphysical philosophy versus spirit of the age. Modern philosophers offer a new paradigm in the way of doing philosophy. The new spirit of modern philosophers declared as if giving criticism on traditional western metaphysics (since Aristotle) that are considered irrelevant. This paper intends to show the argument between traditional metaphysical and modern philosophers who criticize metaphysics. The author will make a philosophical synthesis to obtain enlightenment to the position of human beings in the space of time. Using the method of Hegelian dialectic (thesis-antiteses-synthesis), this topic will be developed and assessed in accordance with the interests of this paper.
\end{abstract}

Keywords: critics, metaphysics, modern philosophers

\section{INTRODUCTION}

Philosophy is a subjective thought process conscious and reflective to find essential meanings of objects devised by the human mind in life. The term philosophy comes from the Greek: philos or philein means love, and sofia means wisdom or truth. So, philosophy means love of wisdom or love of truth. Philosophy begins with a sense of wonder or awe will be a particular object, and then stimulates the human subject as homo rationale (Aristotle) to think and conduct exploration of thoughts. This is the condition when human began to make a philosophical reflection.

In doing philosophical reflection, there are many methods, ways and systems. Philosophical system which is considered the oldest and classic in the history of philosophy is metaphysical thought. It is the branch of philosophy which reflects everything behind it seems. Problematics of metaphysics itself is generally divided into three (3) main things, namely: the question of ontology, cosmology issues and problems anthropology. Philosophical activities actually is metaphysically thinking. Immanuel Kant (1724-1804) said that all philosophy must begin or start with whether metaphysics is possible. By this way of thinking, metaphysical philosophizing is a conditio sine qua non or absolute necessity. Popular thought of Kant is criticism of reason or criticism pure ratio (critic the reinen Vernunft). 
Transcendental -metaphysical dimension provides quality content on the human way of doing philosophy in the history of philosophical thought for centuries. At first, metaphysics is regarded as a pure philosophy of each characteristic of philosophy. Therefore, the philosophy should study about the object or the substance of the abstract-metaphysical world of ideas. Metaphysics is claimed as a school of philosophy that is against realism. Theology hegemony and religion affirm metaphysical thinking patterns. This belief arises from Ancient Greek to the Middle Ages.

However, the philosophical faith (of Karl Jasper) is collapsed when the modern age since auflaerung era and renaissance era, there are many philosophers who provide alternative thinking (critical judgement) against metaphysics or the essence of reality. Long debate between metaphysics and anti metaphysics continues among philosophers. The philosophers eventually drift into the mainstream of mutual criticism in question of the nature of reality. Hegel criticized Kant, Marx criticized Hegel, Habermas criticizes Marx, and finally Heidegger also criticizes traditional metaphysics (Aristotle).

This article shows the contradiction between metaphysics and metaphysics opponent happens on the history of philosophy. The philosophers who maintain metaphysics represents the classictraditional western metaphysics, while opponents of metaphysics is represented by the moderncontemporary philosophers who developed the modern philosophy of each line with the changing times. The description will begin with the metaphysical position (thesis), then the position of modern school of thought towards metaphysics (antithesis) and finally followed by a critical evaluation by the author (synthesis).

\section{METHODS}

The method used in this paper is a method of Dialectics of the famous philosopher George Wilhelm Friedrich Hegel (1770-1831). Hegel's dialectical method consists of three (3) main processes, namely: in the first phase (thesis) that shows his opponent (antithesis) in the second phase and finally the third phase reconciles the first and second phase (synthesis). In the synthesis, thesis and antithesis become "aufgehoben", said Hegel (Bertens, 1997). Writers want to get a new enlightenment in the form of a synthesis of the views metaphysics (thesis) with a critique of metaphysics (antithesis) of the nature of the ontological reality.

\section{RESULTS AND DISCUSSIONS}

Etymologically, metaphysics comes from the Greek; ta meta ta physica, which means behind an existence or reality. Terminology of metaphysics was originally used to refer to the works of classical Greek philosopher, Aristotle. At first, Aristotle calls metaphysics as protephilosophia or first philosophy. Aristotle defines the term metaphysics as a kind of science that exists as there is, or there is so far exists. Metaphysics called ontology philosophy as always questioned the essence of exists until the deepest or reflect the realities exist as far as possible.

What is the material object or scope of the study of metaphysics? Brian Garrett (2006) showed the object of study of metaphysics. According to Garret, the key areas of metaphysics are existence, causation, God, time, universals, personal identity, truth (Garret, 2006). The scope of metaphysics consists of the basic things in this life and the principle of which the existence, causation, the Lord, the time, the universality, human identity and truth. In this paper, it will be shown the controversy among metaphysics philosophers versus the philosophers who criticize metaphysics. 
In outlining his metaphysics, Aristotle developed what he called the first philosophical terms. In his work entitled Metaphysics (a term that indicates the position of this work among his other writings items, namely, beyond, or coming after, Physics). Aristotle developed what he called the science of first philosophy (Stumpf, 1982). Through this metaphysics, Aristotle suggested to focus on the typology of knowledge in search for truth or wisdom by humans. Aristotle claimed that every human being in nature has always had an intrinsic and fundamental longing to know or recognize. Through and in metaphysics, every human being wants to acquire the first principle because everything is in reality.

Metaphysics, according to Aristotle, is the analysis of everything that exists in so far. Aristotle, in his Metaphysics, making metaphisics for him the science of any existent, as existent (Stumpf, 1982). Metaphysics covers themes that includes the basic problems of metaphysics (existence) as the essence of the basic substance of all things, material and form, the process of change, potentiality and actuality, the mover is not moved. Metaphysics is the first cause of everything exists. Metaphysics is the first principle and the main cause as the basic foundations of wisdom which gives to human epistemology knowledge truth of reality nature. Aristotle claimed metaphysics as the highest level of abstraction of thought in philosophical reflection. This metaphysics far above transcendental character of all exists physical in reality. Metaphysics is a transphysics philosophical study, far above the power and reach of the catch sensory perception humans.

Immanuel Kant (1724-1804) is one of the greatest philosophers in the history of modern philosophy. Kant's life is divided into two (2) periods: the pre-critical and critical times (Bertens, 1997). In the pre-critical, Kant adopts rationalistic previously pioneered by Christian Wolf (16791754) developed a philosophy that focuses on ethics, morals, logic and theology. But the influence of David Hume, though exceptional, made Kant decided to abandon rationalism and switch to criticism. Criticism is a philosophy that began by first investigating the capabilities and limits of ratio which may be for humans.

Rationalism, according to Kant, focused on all dimensions or prior elements in knowledge or human recognition. Kant criticizes empiricism initiated by John Locke, David Hume and William Barkley that only emphasizes the effect of the introduction of the dimension or aspect of experience in human knowledge. Empiricism emphasizes posteriori elements that emerge from the human sensory experience as the dynamics of the human journey in time and space.

Kant then took a critical position. With critical philosophy, Kant showed that rationalism and empiricism both have drawbacks or shortcomings. Rationalism will not be able to provide a consistent coherent argument about the metaphysical claims that they formulate good about God, nature and soul. Kant showed that human recognition is the result of a fusion or synthesis of apriori elements with a posteriori elements. Kant's philosophical outlook confirms that it is still possible metaphysics, and metaphysical possibilities this opens the way for the achievement of theoretical knowledge to humans in an effort to understand all exists in reality of the human sensory capabilities. Nevertheless, Kant thought too ambiguous and ambivalent. Because he was in the end caught up in thinking that metaphysical as well. He still maintained a way of doing philosophy that promotes transcendental philosophy. He claimed that rationalism is not able to explain God, the soul and nature perfectly. By this, he supports and confirms the position of metaphysics as a philosophical thesis is correct.

German idealism culminates in G.W.F. Hegel previously developed other philosophers such as Fichte and Schelling. In assessing the nature of existence, Hegel is a philosopher who proclaimed the philosophical belief that the essence of all exists is the idea itself. According to him, exists is only the absolute idealism. Metaphysics is built on a philosophical claim that all existing only in the ideal level. So things that exists is only a mere idealism. 
Hegel proposed a fundamental proposition that: what is rational is real or exists, and what is reality is rationality itself. "What is rational is real, and what is real is rational" (Stumpf, 1986). With this, Hegel would indicate that the extent of measuring the ratio of reality itself. The reality is the whole thought process. So, the idea of the one thinks of himself/herself. Reality entirely is the Spirit who gradually becomes aware of itself (Bertens, 1997). The nature of metaphysics, according to Hegel is Absolute Spirit.

When was the era of modernization started? The term modernization comes from the Latin word "moderna" which means now, the new or the present, German: jetztzeit (Hardiman, 2007). This means that people live in modern times, means that human life must always be recognized and understood in the context of space-time or actuality. However, this paradigm is significant in the philosophical sense. While many European historians agree that the birth of the modern age in Europe occurred since the year of 1500 A.D. This era was marked by the revolution of science and science massively in aspects of science, social, economic, technological, industry and even information. This era is also known as the Enlightenment: the renaissance or aufklaerung.

The dominant social pattern of modern society is characterized by the awareness of the importance of subjectivity dimensions or elements of human individuality. Identify more explicitly shown or expressed. Identity of familly, ethnicity, religion, ethnicity, race, political identity, the party, the professions, job specifications etc. are the aspects of human identity that marked modern era. Human existence is not to be constant or steady-static, but dynamic, evolutionary and change according to human consciousness as the dynamics and the breath of the times. Awareness of selfesteem and human dignity (humanism) in the realm of praxis begins throughout the world, everywhere, especially on the Continent of Europe such as Italy, Germany, and France.

Along with the dynamics of modernity or contemporary consciousness, the appearance of philosophy in the modern era is characterized by the presence of a character patterned philosophizing subjective, critical and innovative to the dynamics of progress towards the development of better and better. Modern philosophy emerged as a new way of doing philosophy protest old way of metaphysical paradigm. Metaphysics criticized, challenged and questioned. Metaphysical philosophy is patterned abstract-idealistic-monistic prioritizing unity, totality-theological character and questionable actual relevance in the context of the present momentum. Modern philosophy criticized that the ratio of human are more important than faith or religious belief. Subjectivity is more important than the collectivity. The physical world is more important than metaphysical elements.

The modern philosophers finally break away from the influence of traditional metaphysics patterned cosmic-theological-ortodox. They, the modern philosophers, conscious and free themselves from the fascination of nature or the cosmos and began to take distance from nature. Paradigm shifted their thinking from metaphysical thoughts to thoughts that are practical-empirical. Following Van Peursen, this attitude is a natural transition from natural to ontological functional thought, or in the category of Comte, a shift from the metaphysical stage to the positive phase (Hardiman, 2003). The influence of metaphysics rocked and swayed by the modern philosophers. How and what kind of criticism it happen?

Philosophical view of traditional metaphysics (classic) is considered by Martin Heidegger as a philosophical paradigm that has both fundamental and significant weaknesses. Traditional western metaphysics are considered irrelevant to the current condition of man as a historical being. Criticism was raised by a stream of existentialist philosopher; Martin Heidegger.

Heidegger (1929) confirmed his attitude towards the view that considers the paradigm of Western philosophy which is not concerned with the problems of human existence in the present momentum. He considered that the views of classical metaphysics (Aristotle) to the metaphysics of the medieval philosopher ignore dimension of human existence. Therefore, according to Heidegger, the 
idea of metaphysics should not far beyond the reach of human (God), but must be grounded on the presence or the dimensions of human existence (existence).

"From this we conclude that metaphysics inquiry must be posed as a whole and from the essential position of the existence. Our existence in the community of in the community of researchers, teachers and students -is determined by science. What happens to us, essentially, in the grounds of our existence, when science becomes our position (Heidegger, 1929)? Heidegger's words actually give criticism in perspective/old metaphysics paradigm patterned transendent, and ignore the human dimension of immanence as spatial and temporal beings in present.

Heiddeger criticizes western metaphysics as a science project that puts human beings transcendental. This transcendence of human distanced position from presence (history) in order to achieve genuine knowledge and the objective. The point to be reached is the aspect of universality and objectivity. Western metaphysics transcendental rated bring danger to the existence of human being. Western metaphysics bring the discrepancy and disparity in human beings as it makes a significant separation (dichotomy) between the subject and the object. Western metaphysics suffered amnesia will be a problem of human existence. As a result, humans forget the "being" in the context of human existence that is spatial and temporal in the totality of history. The forgetfulness of western philosophical tradition of "Beings", lies in distinguishing between "Being" with "B" and "beings" with "b". "Beings" is interpreted the same as the "beings". For Heidegger, Being (das sollen) should be something that is universal; it was above all the particularity. Being actually is something that includes and goes beyond the whole in existence.

Metaphysical thinking of Kant's argument is built on the basis that the dimensions of the introduction (ontology-epistemic) humans apart or have no connection at all with the aspect of experience (aposteriori). According to Hegel, Kant's view does not have a strong base-strong epistemology. By saying: "All that is real is rational and everything that is rational is real" (Bertens, 1997), Hegel would indicate that the extent of Being covers an area of thought or rationality itself. Basic exists in everything contained in an Absolut subject. Absolut subject was the idea that thinking of itself. Moreover, with the idea of dialectics (thesis-antithesis-synthesis), Hegel would reconcile the truth between rationalism with empiricism. Thus, according to Hegel, dimension of human recognition is not located on the outside or away from the reach of human, but it is within human himself. The recognizing of ratio or human reason depends on the presence in the real reality of human beings who have senses.

Karl Marx (1818-1883) admired Hegel's philosophy and developed his philosophical ontology of the word dialectics. Marx considered that the Hegelian dialectic only emphasized the brain (logical), and was not grounded in the realm of real-life practice. Marx echoed back the idea of materialism, which is further divided into two (2) categories namely: dialectical materialism and historical materialism. Dialectical materialism proposed in 1891 by the Russian philosopher named G. Plekhanov. Historical materialism was not initially used by Karl Marx, but later used for the first time by F. Engels, when Marx had died.

Karl Marx criticized the idea of building by Hegel that losing its material relevancy. "But Hegelian dialectic runs on his head and he (read: Marx) want to put it on his feet" (Bertens, 1997). It means, the Hegelian dialectic was limited in idea, while Marx would make it as material. When Hegel said that nature is the result of the Spirit or the Absolute Idea, Marx said that everything (being) which is spiritual is the result of material and vice versa.

Marx said that human life is always directed towards materialism. It has a strong philosophical belief that the totality of human history or oriented towards specific economic conditions, namely communism, in which private property would be replaced with common property. At this point, the good and happiness of mankind is fulfilled perfectly in the world of reality. It shows the means of 
production is important in determining the relations of production. With the "relations of production" for the purpose of human relationships to one another on the basis of its position in the production process (Bertens, 1997). In turn, the relations of production determine the processes and social relations that occur in the reality of society. Economic relations will also determine the superstructure of ideology statement.

By relying on the ideology of materialism, Marx indicated that communist society will dominate the world, making the role of religion to be more fragile and disappear in time. His famous claims "religion is the opium to the people" suggests that humans who embrace the critique of religion is a human being living in the world of false idealism or imaginative-fantasy world. Religious man detached from the reality of the fact itself. Thus, Marx criticized Hegel by stating that absolute materialism is the one that controls the reality of society, not idea. The materials make up the materials, and any material forms the idea. But materialism is the main meeting point or the center point of its symmetric.

After Marx asserting his claims that materialism is the basis of existing (reality), emerged the effort to reform this materialistic paradigm. Critical theory pioneered by Max Horkheimer and his colleagues from the Frankfurt School was originally an attempt to overcome the economic determinism of Marxism embraced Orthodox (Hardiman, 2003). Critical theory attempts to break the ontological building-epistemic Marx is a new dynamic in understanding the reality (being) of people in social life. Way of thinking, rationalistic-empiric previously produced various storm of the social crisis in the reality of society and humans. Habermas criticized western thinkers who tend to be instrumentalistic rationalistic and mechanistic. Habermas offered a new model of rationality.

Habermas gave a new paradigm of the dialectic of enlightenment namely: communicative rationality. Habermas maintained the normative content of modernity, the rationalization of culture, community, social, political and human personality with communicative rationality. For communicative rationality, which is paradigmatic not the relationship of a subject deserted with something in the objective world that can be imagined and manipulated, but the relationship intersubjective built by subjects who can speak and act if they were talking about something (Habermas, 1981). Humans used language in communication with others. If rationalization goes according to the contents of normative, modernization will be able to create a state of integration of culture, society and socialization (Habermas, 1987). Modern rationality brought lot dangers in human reality: alienation, discrimination, the erosion of meaning and psychopathology. Habermas believed in the existence of a discourse framework for the achievement of objectivity which he called the validity of the claims. Subjects were able to produce the validity of claims that would have a good communicative competence and ideal by themselves.

We have seen a contradiction panoramic view of the philosophers about the nature of the metaphysics of the history of classical philosophy to modern and even postmodern now. Conflictual ideas is very strong shades visible in the rhythm of a philosophical debate about the nature of the Being or exists. Traditional western metaphysics (Aristotle), Kant and Hegel were sharply criticized by Heidegger, Marx and Habermas.

Metaphysics is a speculative philosophy that deals with the study of the problems surrounding the being. Metaphysics remains the basic philosophical claims that the nature beings are the transcendent character, far beyond the empirical reality. This means that Being should be a constant essence, fixed, stable, unchanging, beyond the range of human knowledge or experience. However, this claim was contested by modern philosophers even postmodernists who fought grounding abstract transcendent in the realm of physics (real-immanence). Idealism metaphysical that is away from the concreteness of real human experience is going to be practised and actualized and landed in the realm of immanence of man in current space and time. 
Criticism of the modern philosophers against metaphysics would indicate that the paradigm of the traditional philosophical classics should not just stay in the trancendental abstraction. If so, the metaphysics will only stay depends on its trancendental sky. It will lose the spirit of relevance in the present moment of the spatial and temporal human history. Metaphysics should not be absolutized as the singular paradigm in making philosophical reflection. Since it will only make the power of human philosophizing way to become stiff, dry, deterministic, orthodox and irrelevant in context and times that are always dynamic, evolutionary, flowing, changing and evolving.

In the context of metaphysical anthropology or the study of human philosophy, philosophical paradigms should also discuss actual problems of contemporary of human being. Human is not only spirit (idea), but also consists of physical (body). Therefore, philosophical discussion does not have to be stuck on the technical-material perspective degrading idealistic dimension. Discourse on the nature of the social, natural and human person must synthesize the debate between thesis (metaphysics) and the antithesis of traditional (anthropological dimension) present in actual fact of human. Only by this, we can get a balance and harmony as well as the ideal integration between the classical metaphysical paradigm and the paradigm of modern philosophy.

Sharp criticism against metaphysics does not cause the elimination of metaphysics as a branch of philosophy, but opened the way for synergy with the real world and praxis of human life (Jolasa, 2014). Metaphysics somehow cannot be absolutely blamed, because modern philosophy also took inspiration from that anachronistic or out of dated traditional metaphysics. Thus, metaphysics should also not be feasible hated or discriminated against or even abandoned. Also, critical reflection of modern philosophers should not have to be praised and cherished in the way of doing philosophy. We must synthesize both of them. That in philosophizing, metaphysics requires a dynamic modern way of doing philosophy over time and era as inspiration for metaphysics. Conversely, modern way of philosophizing should not only put itself without metaphysics because it will fall into misleading praxis. It takes a dialectic, collaboration, participation and communicative dialogue between metaphysics with a view of contemporary philosopher in modern era now. This synthesis can be a golden bridge connecting the classical period epistemological continuity with the dynamics of modern philosophizing until the future. In the end, we do not only live in the classical metaphysics or just absolutizing modern way of doing philosophy course. But we are philosophers who perform double movement or between movements in maintaining the feel of a traditional metaphysics-classic while being open to accept the modern philosophy that continues dynamically as the human journey in time and space. We still embrace the classical metaphysics and modern philosophers that familiar with the views of the present and together continue searching for wisdom, truth and enlightenment in this life. We still need the classic metaphysical philosophy and modern philosophy as a thirst-quenching for our philosophical intellectual pilgrimage. Only then, we can maintain the dialogue interconnectedness of dynamic, creative and contextual philosophy from each age.

\section{CONCLUSIONS}

When the classical philosophers maintain medieval metaphysics as the only way of doing philosophy, the modern philosophers say no! When modern philosophers criticize against traditional metaphysics; metaphysics was not immediately die or stop growing. This also happens conversely when mankind has entered the 21st century, transcendental metaphysical character is not lost in the era of modern science and technology today. There is always a possibility of a middle ground in the form of dialectic, dialogue and harmonious synthesis.

Although criticized, metaphysics still exists and remains a vital presence. Even though it was criticized, metaphysical position has strengthened. Metaphysics remain as a branch of philosophy that 
is actual, dynamic and resonated over the ages. Though modern philosophers who criticize metaphysics as a philosophy that is transcendent, it confirms the existence and perfected metaphysics. Every wise philosopher will retain the metaphysical method but they also need to be open-minded to receive the brilliant ideas of innovative modern philosophers over the ages. Because we are human, every philosopher in this age is creatures, living on earth, but not forever remains in earth. We are still in the process of becoming, continued to make pilgrimages to the highest Ultim possibilities that can still be achieved in reality. We need spirit, God, nature, matter, ourselves, our fellow human beings, technology, science in the totality of our present existence are spatial and temporal. "I appreciate the existence of a concrete subject in the past, present and future", only with this, metaphysical anthropology stays lasting resonated in the vortex of human.

\section{REFERENCES}

Bertens, K. (1997). Ringkasan Sejarah Filsafat. Yogyakarta: Kanisius

Garret, B. (2006). What is This Thing Called Metaphysics. London and New York.

Hardiman, F.B. (2007). Filsafat Modern, dari Machiavelli sampai Nietzche. Jakarta: Gramedia Pustaka Utama.

Hardiman, F.B. (2003). Melampui Modernisme dan Positivisme. Yogyakarta: Kanisius

Habermas, J. (1981). Theorie des Kommunikativen Handelns I. Frankfurt am Main: Shurkamp

Habermas, J. (1987). The Philosphy Discourse of Modernity. Massachussets: The MIT Press.

Heidegger, M. (1929). What is Metaphysics? (The basic text of Heiddeger's inaugural lecture at the U. of Freiburg in 1929 (an Afterworld and an introduction were added later). Based on a translation by David Farrel Krell.

Jolasa, V.Y. (2014). Sylabus Antropologi Metafisik S2 Filsafat. Depok: Universitas Indonesia.

Stumpf, S.E. (1982). From Sokrates to Sartre (A History of Philosophy). New York: McGraw-Hill 